\title{
Front Matter: Volume 10071
}

, "Front Matter: Volume 10071," Proc. SPIE 10071, Single Molecule Spectroscopy and Superresolution Imaging X, 1007101 (17 April 2017); doi: 10.1117/12.2276699

SPIE. Event: SPIE BiOS, 2017, San Francisco, California, United States 


\title{
Single Molecule Spectroscopy and Superresolution Imaging $X$
}

\author{
Jörg Enderlein \\ Ingo Gregor \\ Zygmunt Karol Gryczynski \\ Rainer Erdmann \\ Felix Koberling \\ Editors
}

28-29 January 2017

San Francisco, California, United States

Sponsored by

SPIE

Co-sponsored by

PicoQuant Photonics North America Inc. (United States)

Published by

SPIE 
The papers in this volume were part of the technical conference cited on the cover and title page. Papers were selected and subject to review by the editors and conference program committee. Some conference presentations may not be available for publication. Additional papers and presentation recordings may be available online in the SPIE Digital Library at SPIEDigitallibrary.org.

The papers reflect the work and thoughts of the authors and are published herein as submitted. The publisher is not responsible for the validity of the information or for any outcomes resulting from reliance thereon.

Please use the following format to cite material from these proceedings:

Author(s), "Title of Paper," in Single Molecule Spectroscopy and Superresolution Imaging X, edited by Jörg Enderlein, Ingo Gregor, Zygmunt K. Gryczynski, Rainer Erdmann, Felix Koberling, Proceedings of SPIE Vol. 10071 (SPIE, Bellingham, WA, 2017) Seven-digit Article CID Number.

ISSN: 1605-7422

ISSN: $2410-9045$ (electronic)

ISBN: 9781510605831

ISBN: 9781510605848 (electronic)

Published by

SPIE

P.O. Box 10, Bellingham, Washington 98227-0010 USA

Telephone +1 3606763290 (Pacific Time) · Fax +1 3606471445

SPIE.org

Copyright @ 2017 , Society of Photo-Optical Instrumentation Engineers.

Copying of material in this book for internal or personal use, or for the internal or personal use of specific clients, beyond the fair use provisions granted by the U.S. Copyright Law is authorized by SPIE subject to payment of copying fees. The Transactional Reporting Service base fee for this volume is $\$ 18.00$ per article (or portion thereof), which should be paid directly to the Copyright Clearance Center (CCC), 222 Rosewood Drive, Danvers, MA 01923. Payment may also be made electronically through CCC Online at copyright.com. Other copying for republication, resale, advertising or promotion, or any form of systematic or multiple reproduction of any material in this book is prohibited except with permission in writing from the publisher. The CCC fee code is $1605-7422 / 17 / \$ 18.00$.

Printed in the United States of America.

Publication of record for individual papers is online in the SPIE Digital Library.

\section{SPIE. DIBRARY}

Paper Numbering: Proceedings of SPIE follow an e-First publication model. A unique citation identifier (CID) number is assigned to each article at the time of publication. Utilization of CIDs allows articles to be fully citable as soon as they are published online, and connects the same identifier to all online and print versions of the publication. SPIE uses a seven-digit CID article numbering system structured as follows:

- The first five digits correspond to the SPIE volume number.

- The last two digits indicate publication order within the volume using a Base 36 numbering system employing both numerals and letters. These two-number sets start with 00, 01, 02, 03, 04, 05, 06, 07, 08, 09, OA, OB ... OZ, followed by 10-1Z, 20-2Z, etc. The CID Number appears on each page of the manuscript. 


\title{
Contents
}

\author{
$\checkmark$ Authors \\ vii Conference Committee
}

\section{FLIM, FRET AND FCS I}

1007102 Quantitative fluorescence correlation spectroscopy on DNA in living cells [10071-1]

\section{NANOSCOPY AND SUPERRESOLUTION MICROSCOPY III}

10071 OE Combining PALM and SOFI for quantitative imaging of focal adhesions in living cells [10071-13]

NEW DEVELOPMENTS IN METHODS AND SYSTEMS

10071 ol Correlated fluorescence-atomic force microscopy studies of the clathrin mediated endocytosis in SKMEL cells [10071-17]

$100710 \mathrm{~J} \mathrm{Improved} \mathrm{timing} \mathrm{and} \mathrm{diffusivity} \mathrm{measurement} \mathrm{in} \mathrm{single-molecule} \mathrm{recycling} \mathrm{in} \mathrm{a}$ nanochannel [10071-18]

BIOLOGICAL APPLICATIONS OF SINGLE MOLECULE DETECTION TECHNIQUES

10071 OK Molecular counting of membrane receptor subunits with single-molecule localization microscopy (Invited Paper) [10071-19]

$10071 \mathrm{OL}$ Single cell genomic quantification by non-fluorescence nonlinear microscopy [10071-20]

FLIM, FRET AND FCS II

$10071 \mathrm{OP} \quad$ Imaging cytochrome $\mathrm{C}$ oxidase and $\mathrm{F}_{\mathrm{o}} \mathrm{F}_{1}$-ATP synthase in mitochondrial cristae of living human cells by FLIM and superresolution microscopy [10071-24]

$100710 Q \quad$ 16-Ch time-resolved single-molecule spectroscopy using line excitation [10071-25] POSTER SESSION

$100710 X$ Enhanced simulator software for image validation and interpretation for multimodal localization super-resolution fluorescence microscopy [10071-32] 
$100710 Z$ Quantitative evaluation of the accuracy and variance of individual pixels in a scientific CMOS (sCMOS) camera for computational imaging [10071-34]

1007111 Probing single processive molecular motors with high-speed optical tweezers and fluorescence microscopy [10071-37] 


\section{Authors}

Numbers in the index correspond to the last two digits of the seven-digit citation identifier (CID) article numbering system used in Proceedings of SPIE. The first five digits reflect the volume number. Base 36 numbering is employed for the last two digits and indicates the order of articles within the volume. Numbers start with 00, 01, 02, 03, 04, 05, 06, 07, 08, 09, 0A, 0B...0Z, followed by 10-1Z, 20-2Z, etc.

Bailey, Elizabeth, 0 ol

Bennett, Keith, $0 Z$

Biskup, Christoph, OP

Börsch, Michael, OP

Capitanio, M., 11

Davis, Lloyd M., OJ

Deschout, Hendrik, OE

Dietz, Marina S., OK

Erdélyi, Miklós, OX

Feletti, Lely, OE

Foertsch, Franziska, OP

Fricke, Franziska, OK

Gajdos, Tamás, OX

Gardini, L., 11

Ghioni, Massimo, $0 Q$

Gulinatti, Angelo, $0 Q$

Heilemann, Mike, OK

Heitkamp, Thomas, OP

Hodges, Cameron, 02

Hoffmann, Birgit, OP

Hoppe, Adam, 01

Hor, Amy, Ol

Hummer, Gerhard, OK

Ilchenko, Mykhailo, OP

Ingargiola, Antonino, $0 Q$

Kafle, Rudra P., 02

Kang, Lin, Ol

Karathanasis, Christos, OK

Kota, Divya, OL

Krüger, Carmen, OK

Lasser, Theo, $\mathrm{OE}$

Lerner, Eitan, $\mathrm{OQ}$

Liu, Jing, OL

Lukes, Tomas, OE

LuU, Anh, Ol

Malkusch, Sebastian, OK

Meiners, Jens-Christian, 02

Michalet, Xavier, $0 Q$

Mrowka, Ralf, OP

Noßmann, Silke, OP

Novák, Tibor, OX

Pavone, F. S., 11

Peronio, Pietro, $\mathrm{OQ}$

Radenovic, Aleksandra, $\mathrm{OE}$

Rech, Ivan, $0 Q$

Scott, Brandon, OI

Sharipov, Azat, OE

Sinkó, József, OX

Smith, Steve, ol
Starke, Ilka, OP

Takahashi, Teruo, $\mathrm{OZ}$

Wang, Bo, OJ

Watanabe, Shigeo, $0 Z$

Weiss, Shimon, OQ 
Proc. of SPIE Vol. 10071 1007101-6

Downloaded From: https://www.spiedigitallibrary.org/conference-proceedings-of-spie on 26 Apr 2023 Terms of Use: https://www.spiedigitallibrary.org/terms-of-use 


\title{
Conference Committee
}

\author{
Symposium Chairs
}

James G. Fujimoto, Massachusetts Institute of Technology

(United States)

R. Rox Anderson, Wellman Center for Photomedicine, Massachusetts General Hospital (United States) and Harvard School of Medicine (United States)

Program Track Chairs

Ammasi Periasamy, University of Virginia (United States)

Daniel L. Farkas, University of Southern California (United States) and SMI (United States)

\section{Conference Chairs}

Jörg Enderlein, Georg-August-Universität Göttingen (Germany) Ingo Gregor, Georg-August- Universität Göttingen (Germany)

Zygmunt Karol Gryczynski, University of North Texas Health Science Center at Fort Worth (United States) and Texas Christian University at Fort Worth (United States)

Rainer Erdmann, PicoQuant GmbH Berlin (Germany)

Felix Koberling, PicoQuant GmbH (Germany)

\section{Conference Program Committee}

Sohail Ahmed, A*STAR Institute of Medical Biology (Singapore)

Michael Börsch, Friedrich-Schiller-Universität Jena (Germany)

Christian Eggeling, University of Oxford (United Kingdom)

Paul M. W. French, Imperial College London (United Kingdom)

Ewa M. Goldys, Macquarie University (Australia)

Johan Hofkens, Katholieke Universiteit Leuven (Belgium)

Zhen-Li Huang, Huazhong University of Science and Technology (China)

Thomas R. Huser, Universität Bielefeld (Germany)

Maria Teresa Neves-Petersen, International Iberian Nanotechnology Laboratory (Portugal)

Markus Sauer, Universität Bielefeld (Germany)

Shimon Weiss, University of California, Los Angeles (United States)

Andong Xia, Institute of Chemistry (China) 
Session Chairs

1 FLIM, FRET and FCS I

Rainer Erdmann, PicoQuant GmbH (Germany)

2 Nanoscopy and Superresolution Microscopy I

Felix Koberling, PicoQuant GmbH (Germany)

3 Nanoscopy and Superresolution Microscopy II

Jörg Enderlein, Georg-August-Universität Göttingen (Germany)

$4 \quad$ Nanoscopy and Superresolution Microscopy III

Jörg Enderlein, Georg-August-Universität Göttingen (Germany)

5 New Developments in Methods and Systems

Jörg Enderlein, Georg-August-Universität Göttingen (Germany)

6 Biological Applications of Single Molecule Detection Techniques

Ingo Gregor, Georg-August- Universität Göttingen (Germany)

7 FLIM, FRET and FCS II

Ingo Gregor, Georg-August- Universität Göttingen (Germany)

8 Nanoscopy and Superresolution Microscopy IV

Felix Koberling, PicoQuant GmbH (Germany) 